\title{
IMPACTS OF ZINC OXIDE NANO-PARTICLES SUPPLEMENTATION IN BROILER DIETS ON GROWTH PERFORMANCE, SOME CARCASS CHARACTERISTICS AND IMMUNE ORGANS
}

\author{
Haiam S. Abd El-Haliem*, Faten A. M. Attia, H. S. Saber and I. H. Hermes \\ Animal Production Department, Faculty of Agriculture, Suez Canal University, Ismailia, Egypt, PO Box \\ 41522.
}

*Corresponding Author : E-mail:haiam65@yahoo.com

(Received 17/12/2019, accepted 26/2/2020)

\section{SUMMARY}

\begin{abstract}
study was designed to investigate the effect of different levels of dietary nano zinc oxide (NZnO) on growth performance, carcass traits, digestive tract measurements, immune response and economic efficiency of broiler chicks. A total number of 192 unsexed day-old "Cobb" broiler chicks were distributed in a completely randomized design of six treatments with four replicates ( 8 chicks each). The control (T1) contained $100 \mathrm{mg}$ inorganic zinc oxide (IZnO)/kg of diet. Treatments two to six contained 100, 80, 60,40 and $20 \mathrm{mg} \mathrm{NZnO} / \mathrm{kg}$ of diet, respectively. No significant differences were observed between treatments on growth parameters except for feed conversion ratio (FCR) and performance index (PI). However, birds fed $40 \mathrm{mg} \mathrm{NZnO}$ (T5) consumed less feed and recorded the highest LBW, TBWG and the best CPC and CCR compared with the other treatments. The best FCR $(\mathrm{P} \leq 0.01)$, PI $(\mathrm{P} \leq 0.05)$, economic efficiency (EE) and the relative $\mathrm{EE}$ were obtained by $\mathrm{T} 5$. The highest $(\mathrm{P} \leq 0.05)$ breast and thigh $(\mathrm{P} \leq 0.01)$ and the lowest abdominal fat percentages were observed with birds fed the control and T6 (20 mg NZnO) compared to other treatments. Thymus percentage was reduced $(\mathrm{P} \leq 0.01)$ by $\mathrm{T} 5$ compared with control, $\mathrm{T} 3$ and $\mathrm{T} 4$ while the bursa percentage was increased by T4 and T5 compared with the other treatments. It could be concluded that $\mathrm{NZnO}$ at a level of $40 \mathrm{mg} / \mathrm{kg}$ of diet had no harmful effect on health status and could be used instead of the traditional zinc sources in broiler diets.
\end{abstract}

Keywords: Broiler, nano zinc oxide, growth performance, carcass parameters and economic efficiency.

\section{INTRODUCTION}

Zinc $(\mathrm{Zn})$ concentration in feedstuffs is too low to meet poultry requirements, so it is regularly added to poultry feeds. In addition, the readily available zinc pools stored in the animal body are limited; hence daily $\mathrm{Zn}$ supply via diet is vital (Bao et al., 2009). As an essential trace element for humans and animals; $\mathrm{Zn}$ is working as a co-factor in more than 300 metal enzymes and plays a prominent role in many metabolic processes, including protein synthesis (Salim et al., 2008). The insufficient dietary Zn adversely affects proteins and carbohydrates metabolism resulted in poor feed intake, growth rate, feed conversion ratio and reproductive performance. In addition, insufficient dietary $\mathrm{Zn}$ reduced immunity and can lead to skeletal and skin disorders (Navidshad et al., 2016).

The Nation Research Council (NRC, 1994) suggested that Zn requirement for broiler chickens, based on the quality criteria, is $40 \mathrm{mg} / \mathrm{kg}$ diet. However, for most trace minerals, these suggested values are based on the old broiler strains which may be outdated for the broiler strains currently used in commercial production (Leeson, 2005). Therefore, broiler diets are usually supplemented with inorganic trace minerals such as oxides and sulfates above the recommended levels of NRC (1994) for maximizing performance (Leeson and Caston, 2008).

In the upper gut with low $\mathrm{pH}$ milieu, the inorganic trace minerals tend to dissociate. Consequently, the dissociated minerals can interact with other minerals as well as other nutrients in the gastrointestinal tract, making them unavailable for absorption across the small intestine (Yan and Waldroup, 2006). In addition, feeding diets supplemented with high levels of $\mathrm{Zn}$ may influence the balance of other trace elements in the 
body and reduce the stability of vitamins and other nutrients. Furthermore, the long-term application of these diets can cause $\mathrm{Zn}$ residue in the animal body (Zhao et al., 2014) and increase $\mathrm{Zn}$ excretion in the feces which induce environmental pollution (Zhang et al., 2018).

Recently, it was found that dietary supplementation of feed additives in nano form had positive effects on poultry production (Ahmadi and Fariba, 2010). Nour and Yunus, (2010) reported that nanoparticle is a key particle that carries the property as a whole. Moreover, minerals in nanoparticles form can be used as an alternative dietary source of trace minerals (Mohapatra et al., 2014). Asheer et al. (2018) reported that replacing inorganic $\mathrm{Zn}$ with nano $\mathrm{Zn}$ in broiler diets may be improved body weight and weight gain during initial phase and reduced mortality. Also, Hafez et al. (2017) concluded that 40 or $80 \mathrm{mg}$ nano zinc oxide $(\mathrm{NZnO})$ had beneficial effects on the growth performance and was a considerable $\mathrm{Zn}$ source for broiler chicken. In addition, broiler chicks fed diets supplemented with 10, 20 and $40 \mathrm{mg} \mathrm{NZnO} / \mathrm{kg}$ of diet improved performance and reduced mortality due to ascites and $40 \mathrm{mg} \mathrm{NZnO}$ was the best level (Fathi et al., 2016)

The present work was designed to investigate the effect of different levels of nano zinc oxide supplementation in broiler diets on growth performance, some carcass traits, digestive tract measurements, immune response and economic efficiency.

\section{MATERIALS AND METHODS}

\section{Birds and management:}

This study was conducted at the Poultry Research Farm, Department of Animal Production, Faculty of Agriculture, Suez Canal University, Ismailia, Egypt. One hundred and ninety-two, unsexed "Cobb" broiler chicks, one-day-old, were obtained from a commercial hatchery (Ismailia Misr Poultry Company, Ismailia, Egypt). Chicks were wing-banded, individually weighed and randomly distributed into 24 groups of eight chicks each. The average of the one-day live body weight of birds for each group was comparable with an overall mean of $54.51 \pm 0.20 \mathrm{~g}$. Six treatments, four replicates each, were used. Chicks were raised in an open house and caged in brooder batteries with wire mesh floors. Feed and water were supplied ad-libitum. The artificial light was provided daily for $23 \mathrm{hr}$ and one $\mathrm{hr}$ of darkness. The ambient temperature was 34 $35^{\circ} \mathrm{C}$ during the first week of the experiment and gradually decreased $2-3^{\circ} \mathrm{C}$ per week. Ventilation was provided by electric fans. All chicks were kept under the same management, hygienic and environmental conditions during the experimental period which lasted for 6 weeks. Chicks were vaccinated at the $8^{\text {th }}$ days of age with Hitchner and at $22^{\text {th }}$ and $35^{\text {th }}$ with Lasota while the vaccination at the $14^{\text {th }}$ and the $28^{\text {th }}$ days of age was by Gumboro. Birds were observed daily for mortality and the number of dead birds was recorded.

\section{Treatments and the experimental diets:}

Six treatments in a completely randomized design were applied. The first treatment (control) contained $100 \mathrm{mg} \mathrm{ZnO} / \mathrm{kg}$ of diet in inorganic form (IZnO; as recommended by the manual of Cobb, 2015). Treatments two to six were supplemented with nano-zinc oxide (NZnO) at 100, 80, 60, 40 and $20 \mathrm{mg} / \mathrm{kg}$ of diet, respectively. Chicks were fed three types of diets in mash form and were formulated to be iso-caloric and iso-nitrogenous. Starter diet ( 0 to 3 weeks of age; contained $22 \% \mathrm{CP}$ and $3000 \mathrm{Kcal} \mathrm{ME} / \mathrm{kg}$ diet), grower diet (4 to 5 weeks of age; contained $20 \% \mathrm{CP}$ and $3100 \mathrm{Kcal} \mathrm{ME} / \mathrm{kg}$ diet) and finisher diet ( $6^{\text {th }}$ week of age; contained $18 \% \mathrm{CP}$ and $3200 \mathrm{Kcal} \mathrm{ME} / \mathrm{kg}$ diet). The preparation of $\mathrm{ZnO}$ in nano form particles was processed in Nanotechnology and Advanced Materials Central Lab Agriculture Research Center, Giza, Egypt, according to Kumar et al. (2013). Chemical analysis of the experimental samples and diets were performed in the laboratories of Animal Production Department, Faculty of Agriculture, and Suez Canal University according to the procedures outlined by A.O.A.C (1990). The experimental diets composition (starter, grower and finisher) and chemical analysis (calculated and determined) are shown in Table (1).

\section{Growth parameters:}

Individual live body weight (LBW) and feed intake (FI) per replicate were recorded weekly. Average daily gain (ADG), average daily feed intake (ADFI) per chick, feed conversion ratio (FCR), crude protein conversion (CPC) and caloric conversion ratio (CCR) were calculated. Also, the performance index (PI\%) was calculated on the basis of (North, 1981):- 


$$
P I \%=\frac{\text { Live weight in } \mathrm{Kg}}{\text { Feed conversion }} \times 100
$$

Table (1): Formulation and chemical analysis (determined and calculated) of the experimental basal diets.

\begin{tabular}{llll}
\hline Ingredients (\%) & $\begin{array}{c}\text { Starter } \\
(0-3 \mathrm{wk})\end{array}$ & $\begin{array}{c}\text { Grower } \\
(3-5 \mathrm{wk})\end{array}$ & $\begin{array}{l}\text { Finisher } \\
\left(6^{\text {th }} \mathrm{wk}\right)\end{array}$ \\
\hline Yellow corn & 57.00 & 60.60 & 64.90 \\
Soybean meal (44\%CP) & 30.00 & 27.00 & 24.31 \\
Corn gluten meal (60\%CP) & 6.70 & 5.00 & 3.00 \\
Veget.oil (Soybean +sun flower) & 1.82 & 3.01 & 3.92 \\
Limestone & 1.24 & 1.07 & 1.00 \\
Di-calcium phosphate & 1.68 & 1.57 & 1.40 \\
Mineral premix (Zn free) ${ }^{1}$ & 0.25 & 0.25 & 0.25 \\
Vitamin premix ${ }^{2}$ & 0.25 & 0.30 & 0.25 \\
Sodium chloride & 0.40 & 0.50 & 0.37 \\
DL- Methionine & 0.23 & 0.21 & 0.28 \\
L-Lysine & 0.33 & 0.29 & 0.22 \\
Choline chloride & 0.10 & 0.20 & 0.10 \\
Total & 100.00 & 100.00 & 100.00 \\
Chemical determined analysis \% & & & \\
Dry matter & 91.34 & 91.03 & 17.58 \\
Crude protein & 21.65 & 19.87 & 3.15 \\
Crude fiber & 3.65 & 3.44 & 6.76 \\
Ether extract & 4.97 & 5.71 & 5.91 \\
Crude ash & 5.60 & 5.61 & \\
Nitrogen free extract & 55.47 & 56.40 & 3200.26 \\
Chemical calculated values \% ( according & to NRC, 1994) & & 18.02 \\
Metabolizable energy (Kcal/kg) & 3000.64 & 3100.80 & 1.052 \\
Crude protein (CP) & 22.07 & 20.02 & 0.582 \\
Lysine & 1.321 & 1.196 & 0.822 \\
Methionine & 0.610 & 0.553 & 0.771 \\
Methionine + Cystine & 0.984 & 0.896 & 0.384 \\
Calcium & 0.939 & 0.842 & 23.79 \\
A. Phosphorous & 0.450 & 0.422 & \\
Zinc (ppm) & 26.15 & 24.91 & \\
\hline
\end{tabular}

1) Each $1 \mathrm{~kg}$ of vitamin mixture contained: $10.000 .000 \mathrm{IU}$ vit. A, 5.000.000 IU vit. D3, $80.000 \mathrm{mg}$ vit. E, $3.000 \mathrm{mg}$ vit. K3, $3.000 \mathrm{mg}$ vit. B1, $9.000 \mathrm{mg}$ vit. B2, $4.000 \mathrm{mg}$ vit. B6, $20 \mathrm{mg}$ vit. B12, $15.000 \mathrm{mg}$ pantothenic acid, $60.000 \mathrm{mg}$ Nicotinic acid, $2.000 \mathrm{mg}$ Folic acid and $150 \mathrm{mg}$ Biotin.

2) Each $2 \mathrm{~kg}$ of minerals mixture contained: $500.000 \mathrm{mg}$ choline chloride, $150.000 \mathrm{mg} \mathrm{Cu}, 1.000 \mathrm{mg} \mathrm{I} ; 40.000 \mathrm{mg} \mathrm{Fe}$, $100.000 \mathrm{mg} \mathrm{Mn}$. and $350 \mathrm{mg} \mathrm{Se}$.

\section{Slaughtered parameters:}

Two birds were chosen, close to the average body weight, from each replicate (eight birds per treatment) at the end of the experimental period (6 weeks of age). Birds were kept overnight fasted of food with free access to water. After the birds individually weighed, slaughtered and bleed for 3-5 minutes, each bird was feathered. The head was cut off close to the skull and feet with shanks were removed at the hock joint. The carcass evisceration was accomplished by a posterior ventral cut to remove the visceral organs. The inedible parts (blood, feather, head, legs and viscera) and eviscerated carcass were calculated via difference. Dressing (carcass plus giblets), giblets (liver, gizzard and, heart), immune organs (spleen, thymus gland and, bursa of fabricius) and abdominal fat were weighed for each bird. Proventriculus, and the intestine were individually weighed. Each eviscerated carcass was portioned into two halves then the right side was portioned into breast and thigh. The measurements mentioned above were expressed as a percentage of live body weight. 


\section{Economic efficiency (EEf):}

The amount of feed intake during the experimental period for each treatment was multiplied by the price of one $\mathrm{kg}$ of each experimental diet (estimation based on the local current prices at the experimental time). The net revenue was calculated by subtracting the total feed cost from the price of one Kg broiler. The EEf was calculated by dividing the net revenue by the total feed cost.

\section{Statistical analysis:}

Data were subjected to analysis for significance by a one-way ANOVA model (as a completely randomized design) using the General Linear Models (GLM) procedures of SPSS (2018), IBM SPSS statistics, version 22, USA. The following mathematic model was used: $\mathbf{Y}_{\mathbf{i j}}=\boldsymbol{\mu}+\mathbf{t}_{\mathbf{i}}+\mathbf{e}_{\mathbf{i j}}$ where: $\mathbf{Y}_{\mathbf{i j}}=$ the observation on the $\mathrm{j}^{\text {th }}$ individual from the $\mathrm{i}^{\text {th }}$ treatment; $\boldsymbol{\mu}=$ the overall mean; $\mathbf{t}_{\mathbf{i}}=$ the fixed effect of the $\mathrm{i}^{\text {th }}$ treatment; $\mathbf{e}_{\mathbf{i j}}=$ the random error associated with the individual $\mathrm{ij}$.

Treatments differences were considered significant at $\mathrm{P} \leq 0.05$ and $\mathrm{P} \leq 0.01$ for all measurements. Means comparisons were performed using Duncan's multiple range tests (Duncan, 1955).

\section{RESULTS AND DISCUSSION:}

\section{Growth performance and economic efficiency:}

The effect of dietary $\mathrm{Zn}$ supplementation on broiler chickens performance and economic efficiency are shown in Tables (2 and 3). No significant differences were observed between treatment groups in average values of final LBW, TBWG, CCR and CPC, whereas significant differences were detected for FCR $(\mathrm{P} \leq 0.01)$ and $\mathrm{PI}(\mathrm{P} \leq 0.05)$. Numerically, the highest mean value of TBWG was observed with the $40 \mathrm{mg}$ $\mathrm{NZnO}$ treatment in comparison with other treatments with lowest TBWG values obtained from birds fed the control diet (Table 2).

Table (2): Growth performance and feed efficiency parameters of broiler chickens as affected by different levels of dietary nano zinc oxide (mean $\pm \mathrm{SE})$.

\begin{tabular}{|c|c|c|c|c|c|c|c|}
\hline \multicolumn{7}{|c|}{ Zinc source and supplementation level (mg/Kg diet) } & \multirow[b]{4}{*}{ Sig } \\
\hline Inorganic zinc c & xide & \multicolumn{3}{|c|}{ Nano zinc oxide } & \multirow{3}{*}{40 (T5) } & \multirow{3}{*}{20 (T6) } & \\
\hline \multirow[b]{2}{*}{ Parameters } & \multirow[t]{2}{*}{$100(\mathrm{~T} 1)$} & $100(\mathrm{~T} 2)$ & $80(\mathrm{~T} 3)$ & $60(\mathrm{~T} 4)$ & & & \\
\hline & & & & & & & \\
\hline \multirow[t]{2}{*}{ Initial body weight (g/chick) } & 54.75 & 54.23 & 54.38 & 54.26 & 54.59 & 54.84 & \multirow{2}{*}{ NS } \\
\hline & \pm 0.41 & \pm 0.45 & \pm 0.55 & \pm 0.53 & \pm 0.39 & \pm 0.59 & \\
\hline \multirow{2}{*}{ Final body weight (g/chick) } & 2607.40 & 2654.50 & 2651.54 & 2634.72 & 2727.39 & 2651.27 & \multirow{2}{*}{ NS } \\
\hline & \pm 57.88 & \pm 50.36 & \pm 55.93 & \pm 63.54 & \pm 60.48 & \pm 58.89 & \\
\hline \multirow{2}{*}{ Total gain (g/chick) } & 2552.69 & 2600.41 & 2597.16 & 2580.31 & 2672.75 & 2595.88 & \multirow{2}{*}{ NS } \\
\hline & \pm 57.71 & \pm 50.35 & \pm 55.99 & \pm 63.60 & $60.53 \pm$ & \pm 58.72 & \\
\hline \multirow[t]{2}{*}{ Total Feed intake(g/chick) } & 3826.92 & 3799.42 & 3620.61 & 3718.44 & 3550.04 & 3898.44 & \multirow{2}{*}{ NS } \\
\hline & \pm 91.32 & \pm 79.49 & \pm 59.07 & \pm 67.89 & \pm 51.37 & \pm 63.14 & \\
\hline \multirow[t]{2}{*}{ FCR } & $1.483^{\mathrm{a}}$ & $1.451^{\mathrm{ab}}$ & $1.393^{\mathrm{bc}}$ & $1.383^{\mathrm{bc}}$ & $1.369^{c}$ & $1.388^{\mathrm{bc}}$ & \multirow{2}{*}{$* *$} \\
\hline & \pm 0.017 & \pm 0.022 & \pm 0.013 & \pm 0.038 & \pm 0.026 & \pm 0.016 & \\
\hline \multirow[t]{2}{*}{ CCR } & 4.761 & 4.602 & 4.393 & 4.486 & 4.306 & 4.691 & \multirow{2}{*}{ NS } \\
\hline & \pm 0.107 & \pm 0.174 & \pm 0.162 & \pm 0.132 & \pm 0.016 & \pm 0.403 & \\
\hline \multirow[t]{2}{*}{$\mathrm{CPC}$} & 0.305 & 0.296 & 0.285 & 0.285 & 0.279 & 0.303 & \multirow{2}{*}{ NS } \\
\hline & \pm 0.007 & \pm 0.011 & \pm 0.005 & \pm 0.013 & \pm 0.003 & \pm 0.028 & \\
\hline \multirow[t]{2}{*}{ PI \% } & $174.25^{\mathrm{b}}$ & $178.03^{\mathrm{ab}}$ & $185.98^{\mathrm{ab}}$ & $174.70^{\mathrm{b}}$ & $201.025^{\mathrm{a}}$ & $188.76^{\mathrm{ab}}$ & \multirow{2}{*}{$*$} \\
\hline & \pm 7.69 & \pm 7.79 & \pm 5.05 & \pm 9.57 & \pm 8.20 & \pm 2.56 & \\
\hline
\end{tabular}

${ }^{a-c}$ means within each raw followed by different letters differ significantly, $*=P \leq 0.05$,

$* *=P \leq 0.01$ and $N S=$ Non significant

Data of Table (2) showed that feeding NZnO at different levels did not alter birds' feed intake. The lowest feed intake $(\mathrm{P}>0.05)$ and the best FCR value $(\mathrm{P} \leq 0.01)$ were observed by $40 \mathrm{mg} \mathrm{NZnO} / \mathrm{kg}$ diet $(\mathrm{T} 5)$ 
while the worst FCR value was recorded by the control group. Besides, the same group ( $40 \mathrm{mg} \mathrm{NZnO} / \mathrm{kg}$ diet) significantly improved $(\mathrm{P} \leq 0.05)$ PI value, however, $\mathrm{CPC}$ and $\mathrm{CCR}$ values were numerically improved compared with the control group (Table 2). The total mortality was within normal limits and did not exceed 3\%. Similarly, Asheer et al. (2018) found that no significant differences between treatments on final LBW, cumulative FI and cumulative FCR at the $6^{\text {th }}$ week of age when broiler chicks' diets were supplemented with $0.0,25,50,75$ or $100 \%$ of NZnO. Besides, these results agree with El-Katcha et al. (2017) who showed that 60,45 or $30 \mathrm{ppm} \mathrm{NZnO/kg}$ of broilers diet improved growth performance and feed efficiency parameters; however, $15 \mathrm{ppm} \mathrm{NZnO}$ significantly worsen performance. In addition, a reduction in total FI was reported as a result of feeding on $\mathrm{NZnO}$. Furthermore, supplementation of $\mathrm{NZnO}, \mathrm{Zn}$ methionine (organic $\mathrm{Zn}$ ) and mix of organic $\mathrm{Zn}$ and $\mathrm{NZnO}$ at $50 \mathrm{mg} / \mathrm{kg}$ to broiler diet contained inorganic $\mathrm{ZnO}$ significantly increased broiler BWG and enhanced protein efficiency and FCR in comparison with the inorganic $\mathrm{ZnO}$ (Ibrahim et al., 2017). Parallel with the data here, Hafez et al. (2017) reported that $\mathrm{ZnO}$ nanoparticles at 40 or $80 \mathrm{mg} / \mathrm{kg}$ of diet is a considerable source of $\mathrm{Zn}$ for broiler chicken which had beneficial effects on the growth performance but no significant difference in FI. Additionally, $\mathrm{ZnO}$ at 20 or $40 \mathrm{mg} / \mathrm{kg}$ of diet (Fathi, 2016) or $60 \mathrm{mg} / \mathrm{kg}$ of diet (Pathak et al., 2016) improved the growth performance of broiler chicks and reduced mortality due to ascites.

In general, the results of most former studies confirmed that $\mathrm{ZnO}$ nanoparticles at 20 to $60 \mathrm{mg} / \mathrm{kg}$ of diet could be appropriate levels to enhance BWG and achieve a better FCR of broiler chickens (Lina et al., 2009; Zhao, et al., 2014 and Swain et al. 2015) and this was matched with the present work. The improvements resulted from supplementing broilers diets with $\mathrm{NZnO}$ as the only source of $\mathrm{Zn}$ (the current study) or to a basal diet with inorganic $\mathrm{Zn}$ (some previous studies) indicated that $\mathrm{Zn}$ nanoparticles were more available and effective to induce the positive effects on performance parameters. Also, this might be related to the role of $\mathrm{Zn}$ as an integral part of more than 300 enzyme systems involved in energy nucleic acids and protein metabolism (Tabatabaie et al., 2007). Ibrahim et al. (2017) found that $\mathrm{ZnO}$ nanoparticles improved Zn retention, enzymes antioxidant activity and metabolism of broiler chickens which resulted in a better performance. In the contrarily, Mohammadi et al. (2015) revealed that NZn-sulphate ( $80 \mathrm{mg} / \mathrm{kg}$ of diet) decreased BWG of broilers during the period from 1-42 day of age. The conflicting results of different research studies could be related to the differences in the physical and chemical features of different sources of Zn studied.

Data in Table (3) showed that $40 \mathrm{mg} \mathrm{NZnO} / \mathrm{kg}$ of diet (T5) observed the best values of the economic efficiency (1.73) and relative efficiency (112.81). Although the process of producing zinc nanoparticles is expensive (1.3 L.E. per gram of $\mathrm{NZnO}$ ) compared to the traditional form (0.3 L.E. per gram of inorganic $\mathrm{ZnO}$ ); the economic return of $\mathrm{T} 5$ was the highest. This could be due to the lower amount used of $\mathrm{NZnO}$ compared with that of IZnO (40 vs. 100). The lowest FI, highest BWG and the best FCR obtained from T5 in comparison with the rest of the treatments and control. A like with the current results, Badawi et al. (2017) confirmed that a $40 \mathrm{ppm} \mathrm{NZnO/kg}$ of diet gave the highest return and net profit values in spite of the high cost of $\mathrm{NZnO}$ feed additive. Additionally, Swain et al. (2015) reported that $\mathrm{NZnO}$ has been provided economic benefits in poultry. On the other hand, the cost of production and net profit of $\mathrm{NZnO}$ at different levels $(0.0,25,50,75$ and 100\%) of broiler chicken diets were very similar (Asheer et al., 2018).

\section{Carcass characteristics:}

Data in Table (4) showed that different levels of $\mathrm{NZnO}$ had no significant effect on carcass characteristics except for giblet, breast and thigh percentages and this effect was varied and inconsistent. The highest $(\mathrm{P} \leq 0.05)$ breast percentage was observed with birds fed diets supplemented with $80 \mathrm{mg} \mathrm{NZnO}$ (T3) followed by $20 \mathrm{mg}$ (T6) and then IZnO $100 \mathrm{mg}$ (control, T1) compared to the other treatments. However, the higher thigh $(\mathrm{P} \leq 0.01)$ and the lowest abdominal fat percentages $(\mathrm{P}>0.05)$ were resulted with birds fed $\mathrm{T} 1$ followed by T6. Also, birds fed T3 and T6 had the higher $(\mathrm{P} \leq 0.05)$ giblets percentages in comparison with other treatments. Carcass and dressed percentages $(\mathrm{P}>0.05)$ were the highest by T2 $(100 \mathrm{mg} \mathrm{NZnO} / \mathrm{kg}$ of diet) followed by $\mathrm{T} 5(40 \mathrm{mg} \mathrm{NZnO} / \mathrm{kg}$ of diet) and $\mathrm{T} 6$, however, the highest $(\mathrm{P}>0.05)$ inedible parts percentage was observed by $\mathrm{T} 3$. 
Table (3): Economic efficiency of broiler chicks as affected by different levels of dietary nano zinc oxide (NZnO).

\begin{tabular}{|c|c|c|c|c|c|c|}
\hline \multirow[b]{2}{*}{ Item } & \multicolumn{6}{|c|}{ Zinc source and supplementation level (mg/Kg diet) } \\
\hline & $\begin{array}{c}100 \\
{ }^{7} \mathrm{IZnO} \\
(\mathrm{T} 1)\end{array}$ & $\begin{array}{c}100 \\
{ }^{8} \mathrm{NZnO} \\
(\mathrm{T} 2) \\
\end{array}$ & $\begin{array}{c}80 \\
\mathrm{NZnO} \\
(\mathrm{T} 3)\end{array}$ & $\begin{array}{c}60 \\
\mathrm{NZnO} \\
(\mathrm{T} 4) \\
\end{array}$ & $\begin{array}{c}40 \\
\mathrm{NZnO} \\
(\mathrm{T} 5)\end{array}$ & $\begin{array}{c}20 \\
\mathrm{NZnO} \\
\text { (T6) }\end{array}$ \\
\hline Average feed intake (Kg/bird) Starter $=\mathrm{a}^{1}$ & 1.108 & 1.113 & 1.070 & 1.012 & 1.122 & 1.095 \\
\hline${ }^{1}$ Price $/ \mathrm{Kg}$ starter feed (L.E.) $=\mathrm{b}^{1}$ & 6.530 & 6.579 & 6.566 & 6.553 & 6.540 & 6.527 \\
\hline Average feed intake $(\mathrm{Kg} / \mathrm{bird})$ Grower $=\mathrm{a}^{2}$ & 1.705 & 1.715 & 1.699 & 1.743 & 1.654 & 1.623 \\
\hline${ }^{2}$ Price $/ \mathrm{Kg}$ grower feed (L.E.) $=\mathrm{b}^{2}$ & 6.427 & 6.495 & 6.477 & 6.459 & 6.441 & 6.422 \\
\hline Average feed intake $(\mathrm{Kg} / \mathrm{bird})$ Finisher $=\mathrm{a}^{3}$ & 0.878 & 0.883 & 0.787 & 0.803 & 0.799 & 0.875 \\
\hline${ }^{3}$ Price $/ \mathrm{Kg}$ finisher feed (L.E.) $=\mathrm{b}^{3}$ & 6.269 & 6.318 & 6.305 & 6.292 & 6.279 & 6.266 \\
\hline $\begin{array}{l}\text { Total feed cost } \\
+\left(a^{2} \times b^{2}\right)+\left(a^{3} \times b^{3}\right)=c\end{array}$ & 23.699 & 24.045 & 22.990 & 22.934 & 23.008 & 23.047 \\
\hline Average LBW $(\mathrm{Kg})=\mathrm{d}$ & 2.607 & 2.655 & 2.651 & 2.634 & 2.727 & 2.651 \\
\hline${ }^{4}$ Price $/ \mathrm{kg}$ LBW (L.E.) $=\mathrm{e}$ & 23.00 & 23.00 & 23.00 & 23.00 & 23.00 & 23.00 \\
\hline Total revenue (L.E.) $=\mathrm{d} \times \mathrm{e}=\mathrm{f}$ & 59.97 & 61.05 & 60.97 & 60.58 & 62.72 & 60.97 \\
\hline${ }^{5}$ Net revenue (L.E.) $=\mathrm{f}-\mathrm{c}=\mathrm{g}$ & 36.27 & 37.01 & 37.98 & 37.65 & 39.71 & 37.93 \\
\hline Economical Efficiency = $(\mathrm{g} / \mathrm{c})$ & 1.53 & 1.54 & 1.65 & 1.64 & 1.73 & 1.65 \\
\hline${ }^{6}$ Relative Efficiency & 100 & 100.60 & 107.98 & 107.30 & 112.81 & 107.56 \\
\hline
\end{tabular}

Table (4): Carcass characteristics (\% of live body weight) of broiler chicks as affected by different levels of dietary nano zinc oxide (mean \pm SE).

\begin{tabular}{|c|c|c|c|c|c|c|c|}
\hline \multicolumn{7}{|c|}{ Zinc source and supplementation levels (mg/Kg diet) } & \multirow[b]{4}{*}{ Sig } \\
\hline \multicolumn{3}{|c|}{ Inorganic zinc oxide } & \multicolumn{3}{|c|}{ Nano zinc oxide } & & \\
\hline & $100(\mathrm{~T} 1)$ & $100(\mathrm{~T} 2)$ & $80(\mathrm{~T} 3)$ & $60(\mathrm{~T} 4)$ & 40 (T5) & \multirow[t]{2}{*}{20 (T6) } & \\
\hline \multicolumn{6}{|l|}{ Parameters $\%$} & & \\
\hline \multirow[t]{2}{*}{ Carcass } & 77.49 & 78.75 & 77.05 & 77.49 & 78.04 & 77.98 & \multirow{2}{*}{ NS } \\
\hline & \pm 0.41 & \pm 0.51 & \pm 0.53 & \pm 1.05 & \pm 0.39 & \pm 0.61 & \\
\hline \multirow[t]{2}{*}{ Inedible parts } & 22.51 & 21.25 & 22.95 & 22.51 & 21.96 & 22.03 & \multirow{2}{*}{ NS } \\
\hline & \pm 0.41 & \pm 0.51 & \pm 0.53 & \pm 1.05 & \pm 0.39 & \pm 0.61 & \\
\hline \multirow[t]{2}{*}{ Giblet } & $3.49^{\mathrm{ab}}$ & $3.50^{\mathrm{ab}}$ & $3.58^{\mathrm{a}}$ & $3.25^{\mathrm{b}}$ & $3.23^{b}$ & $3.59^{\mathrm{a}}$ & \multirow{2}{*}{$*$} \\
\hline & \pm 0.11 & \pm 0.09 & \pm 0.11 & \pm 0.05 & \pm 0.07 & \pm 0.10 & \\
\hline \multirow[t]{2}{*}{ Dressed } & 80.99 & 82.23 & 80.64 & 80.73 & 81.26 & 81.61 & \multirow{2}{*}{$\mathrm{NS}$} \\
\hline & \pm 0.38 & \pm 0.47 & \pm 0.56 & \pm 1.08 & \pm 0.38 & \pm 0.54 & \\
\hline \multirow[t]{2}{*}{ Breast } & $26.16^{\mathrm{a}}$ & $21.86^{\mathrm{b}}$ & $26.39^{\mathrm{a}}$ & $22.36^{\mathrm{b}}$ & $23.69^{\mathrm{ab}}$ & $26.25^{\mathrm{a}}$ & \multirow{2}{*}{$*$} \\
\hline & \pm 1.56 & \pm 0.97 & \pm 1.05 & \pm 0.78 & \pm 0.97 & \pm 1.28 & \\
\hline \multirow[t]{2}{*}{ Thigh } & $17.73^{\mathrm{a}}$ & $15.04^{\mathrm{b}}$ & $15.54^{\mathrm{b}}$ & $15.34^{\mathrm{b}}$ & $15.45^{\mathrm{b}}$ & $17.03^{\mathrm{a}}$ & \multirow{2}{*}{$* *$} \\
\hline & \pm 0.56 & \pm 0.45 & \pm 0.54 & \pm 0.36 & \pm 0.49 & \pm 0.63 & \\
\hline \multirow[t]{2}{*}{ Abdominal fat } & 0.93 & 1.20 & 1.19 & 1.17 & 1.02 & 0.96 & \multirow{2}{*}{ NS } \\
\hline & \pm 0.07 & \pm 0.08 & \pm 0.13 & \pm 0.14 & \pm 0.12 & \pm 0.10 & \\
\hline
\end{tabular}

${ }^{a-b}$ means within each row followed by different letters differ significantly, $*=P \leq 0.05$,

$* *=P \leq 0.01$ and $N S=$ Non significant.

Comparable to the data here El-Katcha et al. (2017) stated that dressing percentage was significantly improved and abdominal fat weight and its relative weight were decreased by replacing dietary inorganic $\mathrm{Zn}$ with lower levels of organic or NZn. However, Mohammadi et al. (2015) reported that NZn-sulphate and control groups (without added Zn) dramatically reduced carcass yield (\%) and increased abdominal fat (\%) 
at 42 day of age when broilers fed basal diet (without Zn) and basal diet supplemented with Zn-sulphate, Znmethionine, NZn-sulphate, NZn-methionine and NZn-max. at a concentration of $80 \mathrm{mg} / \mathrm{kg}$ of diet. While, Sahoo et al. (2016) reported no significant differences between $\mathrm{Zn}$ source (inorganic, organic, nano-Zn) and levels (0, 15 ppm ZnSO4, 15 ppm Zn-Met., 7.5 ppm Zn-Met., 0.3 ppm NZnO, 0.06 ppm NZnO and 0.03 ppm $\mathrm{NZnO}$ ) on carcass weight and percentages of dressing, breast and thigh of broiler chicken.

\section{Digestive tract parameters and immune organs:}

Dietary levels of nano-zinc had significant effects on chicks' digestive tract parameters and immune organs except for spleen (Table 5). Data revealed that the relative weight of proventriculus at 40 and $100 \mathrm{mg}$ $\mathrm{NZnO} / \mathrm{kg}$ of diet were significantly $(\mathrm{P} \leq 0.05)$ the lower compared with those of the control group. The relative weight of the intestine was decreased by lowering the $\mathrm{NZnO}$ levels with significant differences $(\mathrm{P} \leq 0.05)$ at 40 and $20 \mathrm{mg} / \mathrm{kg}$ of diet compared with the control. Also, dietary $\mathrm{NZnO}$ reduced $(\mathrm{P} \leq 0.01)$ the relative weight of thymus (at 100,40 , and $20 \mathrm{mg} / \mathrm{kg}$ of diet) and improved ( $\mathrm{P} \leq 0.01)$ the relative weight of bursa of fabricius ( 60 and $40 \mathrm{mg} / \mathrm{kg}$ of diet) in comparison with the control.

Table (5): Digestive tract measurements and immune organs (\% of live body weight) of broiler chicks as affected by different levels of dietary nano zinc oxide (mean $\pm \mathrm{SE}$ ).

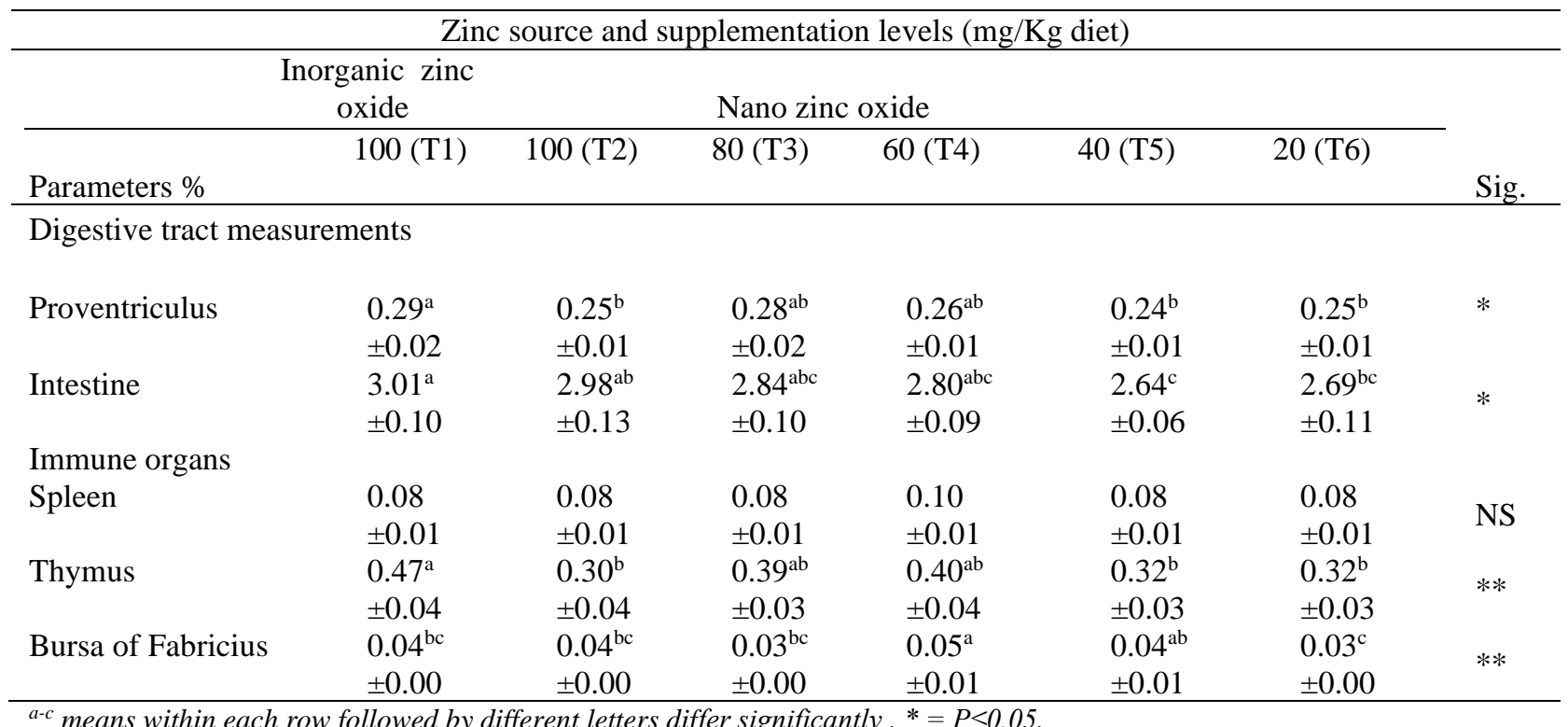

${ }^{a-c}$ means within each row followed by different letters differ significantly, $*=P \leq 0.05$,

$* *=P \leq 0.01$ and $N S=$ Non significant.

The bursa of fabricius is the main lymphoid organ in poultry that has an important function in B lymphocyte differentiation (Schat and Skinner, 2014). In addition, Sahoo et al. (2014) studied the effect of supplementing inorganic zinc (15 ppm $\left.\mathrm{ZnSO}_{4}\right)$, organic $\mathrm{Zn}(15$ and $7.5 \mathrm{ppm} \mathrm{Zn-Met)}$ and $\mathrm{NZn}(0.3,0.06$ and $0.03 \mathrm{ppm} \mathrm{NZnO}$ ) to unsupplemented basal diet (contained $30 \mathrm{ppm} \mathrm{Zn}$ ) on the immune organs of broiler chicks. They concluded that $15 \mathrm{ppm} \mathrm{Zn}-\mathrm{Met}$ and $0.06 \mathrm{ppm} \mathrm{NZnO}$ significantly improved relative weights of the spleen, bursa and thymus in comparison with the rest of the treatments. On the contrary, El-Katcha et al. (2017) found that the replacement of dietary inorganic $\mathrm{ZnO}$ with lower levels of organic $\mathrm{Zn}$ or $\mathrm{Zn}$ nanoparticles significantly improved the thymus and spleen weight and percentages and significantly reduced weight and relative weight of bursa. However, increasing the level of organic $\mathrm{Zn}$ (Zn-polysaccharide complex) increased bursa weight in comparison with those fed a basal diet supplemented with inorganic Zn. This could be explained by that supplementation diets with organic or nano zinc increased thymulin activity; thus, enhancing the immune response through increased maturation of T-lymphocyte and activation of B lymphocytes by T-helper cells (Hudson et al., 2004). Furthermore, Mohammadi et al. (2015) showed that spleen and bursa of fabricius (\%) of broiler chicks were significantly higher when the diet was supplemented with $80 \mathrm{mg} \mathrm{Zn/kg} \mathrm{(inorganic} \mathrm{or} \mathrm{nano)} \mathrm{compared} \mathrm{with} \mathrm{the} \mathrm{unsupplemented} \mathrm{control.} \mathrm{Whereas,} \mathrm{Ahmadi} \mathrm{et} \mathrm{al.}$ (2013) reported that $\mathrm{NZnO}(30,60,90$ or $120 \mathrm{mg} / \mathrm{kg}$ of diet) had no significant effect on digestive and visceral organs of broiler chicks (1-21 day of age) compared with the unsupplemented control. 


\section{Abd El-Haliem et al.}

In conclusion, results of this study indicated that $\mathrm{NZnO}$ at the level of $40 \mathrm{mg} / \mathrm{kg}$ of diet is a considerable $\mathrm{Zn}$ source for broiler chicken with beneficial effects on the growth performance economic efficiency. Moreover, supplementation of $\mathrm{Zn}$ as nano particles to the diets had no harmful effect on birds' health status and reducing the amount of $\mathrm{Zn}$ in the diets resulted in a positive outcome on the environment.

\section{REFERENCES}

Ahmadi, F. and R. Fariba (2010). The effect of different levels of nano silver on performance and retention silver in edible tissue of broilers. World Applied Sci. J., 12: 1-4.

Ahmadi, F.; Y. Ebrahimnezhad; N. Naser and J. G. Ghalehkandi (2013). The effects of zinc oxide nanoparticles on performance, digestive organs and serum lipid concentrations in broiler chickens during starter period. Int. J. Biosci., 3: 23-29.

AOAC (1990). Association of Official Analytical Chemists. Official Methods of Analysis, $15^{\text {th }}$ Edition. Washington, DC, USA.

Asheer, M.; S.J. Manwar; M.A. Gole; S. Sirsat; M.R. Wade; K.K. Khose and S. Sajid Ali. (2018). Effect of dietary nano zinc oxide supplementation on performance and zinc bioavailability in broilers. Indian $\mathrm{J}$. of Poult. Sci., 53: 70-75.

Badawi, M.; M. Ali and A. Behairy (2017). Effects of zinc sources supplementation on performance of broiler chickens. J. of American Sci., 13: 35-43.

Bao, Y.M.; M. Choct; P.A. Iji and K. Bruerton (2009). Optimal dietary inclusion of organically complexed zinc for broiler chickens. Br. Poult. Sci., 50:95-102.

Duncan, D.B. (1955). Multiple range and multiple F test. Biometrics, 11: 1-42.

El-Katcha, M.; A. Mosad Soltan and M. El-badry (2017). Effect of dietary replacement of inorganic zinc by organic or nano particles sources on growth performance, immune response and intestinal histopathology of broiler chicken. Alexandria J. of Vet. Sci., 55: 129-145.

Fathi. M. (2016). Effects of zinc oxide nanoparticles supplementation on mortality due to ascites and performance growth in broiler chickens. Iranian J. Appl. Anim. Sci., 6: 389-394.

Fathi, M.; M., Hydari and T. Tanha (2016). Effect of zinc oxide nanoparticles on antioxidant status, serum enzyme activities, biochemical parameters and performance in broiler chicken. J. Livestock Sci. and Technol., 4: 0713.

Hafez, A.; S.M. Hegazi; A.A. Bakr and H. El- Shishtawy (2017). Effect of zinc oxide nanoparticles on growth performance and absorptive capacity of the intestinal villi in broiler chickens. Life Sci, J. 14:125129.

Hudson, B.P.; W. A. Dozier; J.L. Wilson; J.E. Sander and T.L. Ward (2004). Reproductive performance and immune status of caged broiler breeder hens provided diets supplemented with either inorganic or organic sources of zinc from hatchery to $65 \mathrm{wk}$ of Age. J. Appl. Poult. Sci., 13: 49-59.

Ibrahim, D.; A. H. Ali and A.M. Shefaa El-Mandrawy (2017). Effects of different zinc sources on performance, bio distribution of minerals and expression of genes related to metabolism of broiler chickens. Zagazig Vet. J., 45: 292-304.

Kumar, S.S.; P. Venkateswarlu; V.R. Rao and G.N. Rao (2013). Synthesis, characterization and optical properties of zinc oxide nanoparticles. International Nano Letters. 3: 1-6.

Leeson, S. (2005). Trace mineral requirements of poultry validity of the NRC recommendations. In: Redefining mineral Nutrition. LA Tucker, and JA Taylor-Pickard, Nottingham university press, Nottingham, UK. 107- 117.

Leeson, S. and L. Caston (2008). Using minimal supplements of trace minerals as a method of reducing trace mineral content of poultry manure. Anim. Feed Sci. Tech. 142:339-347. 
Lina, T., Zhu, F., Ren ,H., Jiang, J.Y. and Li, W. (2009). Effects of nano-zinc oxide on antioxidant function in broilers. Chinese J. Anim. Nut., 21: 534-539.

Mohammadi, V.; S. Ghazanfari; A. Mohammadi-Sangcheshmeh and M.H. Nazaran (2015). Comparative effects of zinc-nano complexes, zinc-sulphate and zinc-methionine on performance in broiler chickens. Br Poult Sci, 56:486-493.

Mohapatra, P.; R.K. Swain; S. K. Mishra; T. Behera; P. Swain; N. C. Behura; G. Sahoo; K. Sethy; B. P. Bhol and K. Dhama (2014). Effects of dietary nano-selenium supplementation on the performance of layer grower birds, Asian J. Animal and Veterinary Advances, 9: 641-652.

Navidshad, B.; S. Jabbari and F. Mirzaei Aghjeh Gheshlagh (2016). The New Progresses in Zn Requirements of Poultry. Iranian Journal of Applied Animal Science (IJAS). 6: 763-767.

North, M.O. (1981). Commercial chicken. Production Annual. $2^{\text {nd }}$ Edition, AV., publishing company I.N.C., West post Connecticut, USA.

Nour, A.H. and R.M. Yunus (2010). Demulsification of water-in-oil emulsions by microwave heating technology. World. Acad. Sci. Eng. Tech., 38:188-193.

NRC (1994). Nutrient Requirements of Poultry, $9^{\text {th }}$ Rev. Ed. National Academy Press, Washington, DC., USA.

Pathak, S. S.; K. V. Reddy and S. Prasoon (2016). Influence of different sources of zinc on growth performance of dual purpose chicken, J. Bio. Innov 5: 663-672.

Sahoo, A.; R. K. Swain and S. K. Mishra (2014). Effect of inorganic, organic and nano zinc supplemented diets on bioavailability and immunity status of broilers. Int. J. Adv. Res., 2:828-837.

Sahoo, A.; R.K. Swain; S.K. Mishra; N.C. Behura; S.S. Berura; C. Sahoo; A. Das; A. Mishra and B. Jena (2016). Growth, feed conversion efficiency and carcass characteristics of broiler chicks fed on inorganic, organic and nano zinc supplemented diets. Anim. Sci. Rep.10: 10-18.

Salim, H.M.; C. Jo and B.E. Lee (2008). Zinc in broiler feeding and nutrition. Avian Biol. Res. 1:5-18.

Schat, K.A. and M.A. Skinner (2014). Avian Immunosuppressive Diseases and Immune Evasion. In : Schat KA, Kaspers B, Kaiser P, editors. Avian Immunology. San Diego :Elsevier Ltd. Publishing; 275-297.

SPSS (2018). User's guide: statistics. Version 22. SPSS. Inc. Chicago, IL, USA.

Swain, P.S; D. Rajendran; S.B.N. Rao and G. Dominic (2015). Preparation and effects of nano mineral particle feeding in livestock: a review. Vet World 8: 888-891.

Tabatabaie, M.M; H. Aliarabi; A.A. Saki; A. Ahmadi and S.A. Hosseini Siyar (2007). Effect of different sources and levels of zinc on egg quality and laying hen performance. Pakistan. J. Biol. Sci.; 10: 3476-3478.

Yan, F. and W.P. Waldroup (2006). Evaluation of Mintrex ${ }^{R}$ manganese as a source of manganese for young broilers. Int. J. Poult. Sci. 5:708-713.

Zhang, T.Y.; J.L. Liu; J.L. Zhang; N. Zhang; X. Yang; H.X. Qu; L. Xi and J.C. Han (2018). Effects of dietary zinc levels on the growth performance, organ zinc content, and zinc retention in broiler chickens. Braz J Poult Sci 20:127-132.

Zhao, C.Y; S. X. Tan; X.Y. Xiao; X.S. Qiu; J.Q. Pan and Z.X. Tang (2014). Effects of dietary zinc oxide nanoparticles on growth performance and antioxidative status in broilers. Biol Trace Elem Res 160:361367. 
تأثيرات إضافة الأجزاء النانوية لأكسيد الزنك في علائق بداري التسمين على أداء النمو وبعض خصائص الأبيحة

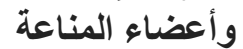

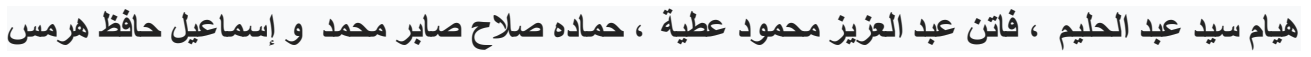
قسم الإتتاج الحيواني والثروة السمكية ـ كلية النراعة - جامعة قناة السويس- مصر.

صُُمت هذه الدراسة لمعرفة تأثير المستويات المختلفة لأكسيد الزنك النانو الذائي على أداء النمو وصفات الذبيحة وقياسات الجهاز الهضمي و الاستجابة المناعية و الكفاءة الاقتصادية لكتاكيت التسمين.

تم استخدام 192 كتكوت تسمين من نوع "Cobb" غير المجنس في عمر يوم قسمت بشكل عشو ائي إلى ستة معاملات ، بكل معاملة أربع مكرر ات بمعدل 8 كتاكيت في كل مكررة.

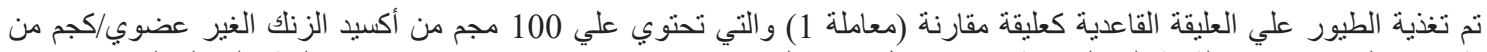
العليقة. بينما المعاملات من الثانية إلي السادسة وتحتوي كل منها علي 100، 80، 60، 40 و و 20 مجم /كجم عليقة علي النتو الي في صورة أكسيد النانو زنك.

و اتضح من النتائج انه لا يوجد فروق معنوية بين المعاملات بالنسبة لمقاييس كفاءة النمو باستثناء كفاءة التحويل الغذائي (FCR) ومؤشر الآداء (PI).

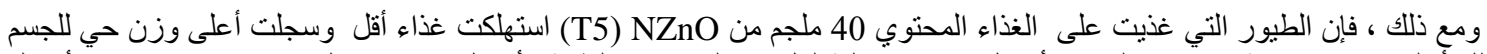

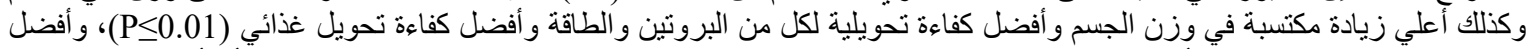

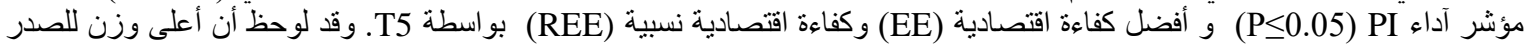

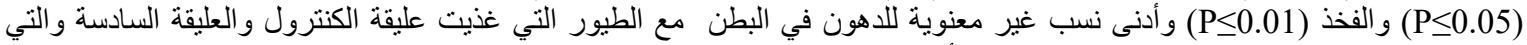
تحتوي20 مجم من NZnO مقارنة مع المعاملات الأخرى.

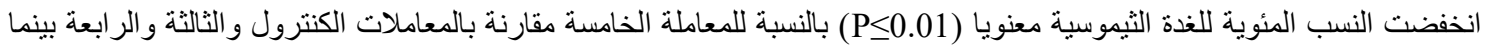

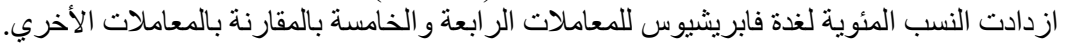

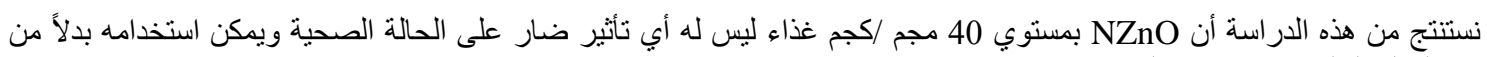
مصادر الزنك التقليدية في علائق التسمين. 